\title{
AZ EURÓPAI REGIONẢLIS FEJLŐDÉS ÉS POLITIKA TÁVLATAI
}

\author{
(Perspectives of Regional Development and Policy in Europe)
}

\section{HORVÁTH GYULA}

\section{Az európai gazdasági tér kohéziója és differenciálódása}

A XX. század utolsó harmadában az európai regionális fejlődésre a globalizáció nyomta rá bélyegét. A gazdaság szervezeti rendszerében a posztfordista struktúrák kerủltek túlsúlyba, a termelési tényezỏk mobilitásának alakításában új szereplők, intézmények és finanszírozási formák jelentek meg. A globalizáció generálta folyamatok többsége eróteljes hatást gyakorolt a nemzetgazdasági és az interregionális terek átrendezódésére. A területi fejlödés jövője szempontjából különoosképpen hét hatótényezó szerepére érdemes figyelemmel lenni (Amin-Thrift 1994, 1995).

Az első globalizációs trend a pénzpiacok növekvő koncentrációja révén rajzolódik ki. A termelést is maga alá gyürő pénzügyi hatalom egyre erỏteljesebben vonja befolyási körébe a világgazdaság szabályozását, az ùzleti döntéseket. A második világméretü változás a tudásigényes rendszerek térhódításában érzékelhető. A tudás termelése, elosztása és cseréje a gazdaság kulcselemévé válik, az e feltételek megléte alapján szelektálódnak a globális és a transznacionális piaci szereplók. A tudásfaktorhoz is szorosan kapcsolódó harmadik globalizációs tényezó a technológia transznacionalizálódása, a technológiák gyors cserélődése, az innovációs reakcióidó csökkenése. A telekommunikáció, az ürtechnikai és a gyógyszeripar, a pénzủgyi szolgáltatások és a mikroelektronikai eszközök fejlódése gyorsabbá teszi a szabványok és a know-how elterjedését. A negyedik globalizációs erőtényezó a globális oligopóliumok terjedése, aminek következtében a nemzeti gazdaságok piacbefolyásoló szerepe mérséklődik, a gazdasági hatalom erővonalai átrendeződnek. A gazdasági és a pénzủgyi reálfolyamatokkal párhuzamosan kibontakozó ötödik elem a transznacionális gazdasági diplomácia megerősödése és a globalizálódó államhatalom intézményeinek fejlődése. A vezető világhatalmak az ủj intézményi formákat saját pozícióik erősítésére használják fel, bár a szervezetek mủködésének szabályozása ugyanakkor gátat is igyekszik szabni e törekvéseknek. A nemzetközi szervezetekben e két erótér közötti küzdelem gyakran az instabilitás érzetét kelti. Az intenzív globális kommunikációval és nemzetközi migrációval hozható összefüggésbe a hatodik globalizációs hatótényezö, a világméretü kulturális csere, a meghatározott térhez nem köthető kulturális jegyek, fogalmak és identitás terjedése és általánossá válása. Az intenzív forgalmú idegenforgalmi helyek, a vendégmunkásokat foglalkoztató városok, a menekullteket befogadó térségek lassan etnikai tảjjá formálódnak. Az elektronikus média által továbbitott általános és közös emberi értékek, a fogyasztói kultusz, a nemzetietlenített etnikai motivumok révén kialakulóban vannak a médiatájak. Az állam és a helyi közösségek igényeit legitimálni szándékozó mozgalmak, a szabadság, a demokrácia, a szuverenitás, az emberi jogok és a polgárság eszméje pedig a posztmodern ideológiai táj képét vetíti elő (King 1991; Smith 
1990). Mindezek a folyamatok önmagukban természetesen nem okoznak kulturális homogenizációt, csupán - bár ez sem jelentéktelen hatás - a helyi kultúrák sokszínüségét fokozzák. S végezetül, az előbb említett hatások közös eredményeként a globalizáció fokozatosan kikezdi a korábbi erős határokat, az áramlási terek adminisztrativ méretei rugalmassá válnak, a termelési és a szolgáltatási hálózatok világméretekben szabadon szerveződhetnek.

A globalizációs folyamatok hatásaira az egyes régiók és városok különbözőképpen reagálnak, adottságaik és az alkalmazott stratégiák függvényében nyertesek vagy vesztesek lesznek. A negatív következményeket elkerülendő, a helyi és a regionális hatóságok érdekeik védelmére intézkedések egész sorát foganatosították. Az alkalmazkodási stratégiák ugyanakkor az egybeolvadás ellenében az elkülönưlést erősítik. Ezt szolgálják például a megélénkülő regionális kulturális mozgalmak és a világ szinte minden pontján egyre eredményesebben fellépő etnikai szervezetek. Kérdés persze, hogy az identitást favorizáló regionális stratégia alkalmas-e a régió nemzeti vagy nemzetközi pozíciójának a védelmére, elegendő fejlesztỏ erőt jelent-e a régió teljesítőképességének növelésében. A válasz nyilván attól függ, hogy a világ mely térségének milyen régiójáról van szó. A fordista típusú ipari központok, a vidéki regionális centrumok vagy a globális metropolisok lényegesen eltérỏ feltételekkel rendelkeznek a hagyományosan értelmezett reakcióképesség szempontjából. $\mathrm{Az}$ alkalmazkodásnak a klasszikus termelési tényezők minösége azonban csak az egyik előfeltétele. A másik - a hálózatos gazdaság müködésébỏl következö új adaptációs kritérium a régió vagy a város szervezetei és intézményei közötti kapcsolatok jellege, a közös célkitüzés intézményesülésének lehetősége, a helyi ösztönzők, a kollektív döntések elökészítése, a társadalmi konszenzus. Ez az új versenyképességi tényezöcsoport tehát azt jelzi, hogy a helyi és a regionális fejlödés sikere már nem csupán szük gazdasági szempontokon múlik, hanem a területi növekedésben érdekelt szereplök szoros koalíciójától, intézményes együttműködésétől is függ.

A posztmodern típusú térfelfogás terjedésének következménye az új területfejlesztési paradigma fokozatos térhódítása. A belső erőforrásokra támaszkodó, az öneröre is építő, a perifériákról kiinduló fejlesztési felfogás lassan polgárjogot nyer a fejlettebb térségek stratégiáiban, söt, egyre több állam központi regionális politikája is az "alulról építkezés" elvét tekinti egyik kiinduló pontjának (Faragó 1991).

A globalizálódás folyamatos lendületben tartja, sőt, esetenként fel is gyorsítja a posztmodern gazdaság szerkezeti átrendeződésének mozgástendenciáit. A 80-as évtizedben megalapozott gazdasági paradigma kiteljesedése Európában az új évezred első évtizedeiben várható, a posztfordista térformáló erők is hosszú ideig éreztetik még hatásukat. Az agglomerációs elönyöket érvényesítő fejlett szolgáltatások bövülése prognosztizálható, és országonként eltérö ütemben tovább folytatódik e tevékenységek koncentrált decentralizácioja. A terjedés sebessége nem kis mértékben azon múlik, hogy a régiók fejlesztési stratégiájukban milyen szerepet szánnak az érett tercier és a kvaterner ágazatoknak, a gazdaság fejlesztésében milyen súlyt képviselnek a magas hozzáadott értéket termelö, klaszterekbe szerveződött ágazatok. A területfejlesztés új felfogása - a globalizáció hajtóeröit a helyi adottságokkal ötvözni képes szakmai kultúra - fontos szelekciós tényezö lesz majd a területi egyenlötlenségek mérséklésében és erősődésében. 


\section{A hosszú távú térformáló folyamatok}

Az új évezred Európájának területi szervezödését, térbeli integrálódásának lehetőségeit elsősorban a XX. század utolsó harmadában kibontakozott térformáló erők befolyásolják.

A területfejlesztési stratégiák meghatározó kiindulási pontjának, a demográfiai viszonyoknak az alakulásában kedvezőtlen trendekkel kell számolni. Az elsö a viszonylag alacsony - évi $0,5 \%$ alatti - népességnövekedés. A lakosság számának emelkedése Dél-Európa országaiban - a termékenység csökkenése miatt - megtorpan. Az várható, hogy Európa népessége 2010 körül fogyni kezd. A másik demográfiai trend a népesség életkor szerinti tagozódásának megváltozása: az átlagéletkor növekedésével párhuzamosan csökken a fiatal korosztályok aránya. A 15 év alatti korosztály aránya 1970-ben még $18 \%$ fölött volt a jelenlegi EU-tagállamok terulletén, 2010-ben pedig már nem éri el a 15\%-ot. E változás egyben a munkaeröpiacokra nehezedö nyomás mérséklödését is elörevetíti. A harmadik fejlödési irányzat a migráció erősödéséhez kapcsolódik: a népesség számának változásában és területi eloszlásában a vándorlás meghatározó jelentóségre tesz szert. Mivel a migráció fố célpontjai a városi terek, az urbanizáció szabályozásában ezzel a tényezóvel különösképpen számolni kell.

Az általános népességi trendek alakulásában azonban jelentỏs területi különbségek kirajzolódására kell számítani (Europe 2000+, 1994). Valamennyi EU-tagállamban megfigyelhető, hogy a népességnövekedés fö csomópontjaivá a déli térségek váltak (Bajorország és Baden-Württemberg Németországban, Murcia, Andalúzia Spanyolországban, Algarve Portugáliában, a Mezziogiorno Olaszországban, a déli régiók Franciaországban stb.). A második demográfiai jellegzetesség az urbanizált terek folyamatos bóvülése a centrumtelepülések lassú népességfogyásával párhuzamosan. E tendencia csupán az Egyesült Királyságban nem érvényesül, ahol a rurális térségek népsürüsége folyamatosan nö, a centrumtelepülések környékén és az ipari térségekben viszont csökken. A harmadik változási irány a tengerparti területek felértékelödéséhez kötődik. A Földközi-tenger partvidékének elmúlt két évtizedben bekövetkezett népességnövekedése hosszú távú folyamatnak tekinthető, ezzel párhuzamosan viszont a tengerrel érintkező országok belsó területein a népességfogyás tovább folytatódik. A negyedik meghatározó népesedési vonulat a nagyvárosokat összekapcsoló fejlódési folyosók körüli népességtömörülések megerősödéséhez kötődik. A német Rajna-, a francia Szajna-, Rhône- és Loire-völgy, az olasz Pó-völgy városhálózatai folyamatos népességnövekedést mutatnak, a déli brit térségek és a görög foútvonalak menti urbanizációs tengelyek szintén fontos növekedési kőzpontok lehetnek a jövő század legelsỏ évtizedeiben.

A fontos gazdasági erővonalaktól, fejlödési tengelyektöl távoli térségek, a hegyvidéki területek és a hanyatló ipari körzetek népességfogyása még hosszú távon komoly gondok elé állítja a területi tervezési szakembereket. A rurális térségekben folytatódó népességmozgások szabályozásában, a hanyatlás ütemének mérséklésében kitüntetett szerepük lesz a kis- és középvárosoknak.

Kedvezó - $\mathrm{s}$ az európai integráció kohéziós hatását is bizonyító - jelenség ugyanakkor, hogy a korábban erős depopulációt mutató határ menti térségek többségében a kedvezőtlen elvándorlási tendenciák megfordultak. A jövöben - az Unió keleti határ 
menti térségei, a spanyol-portugál határszakasz kivételével - az országhatárok menti régiókban stabil demográfiai viszonyokkal lehet majd számolni.

Az európai térségek integrációját befolyásoló második nagy tényezőcsoportot a gazdaság szerkezeti és szervezeti rendszerei jelentik. A nagy szerkezeti átrendezỏdések Európa legtöbb országában - Kelet-Európát nem számítva - már lejátszódtak. A mediterrán régiókban az agrárágazat magas részaránya miatt a második és a harmadik szektor bỏvülése tovább folytatódik, másutt viszont az ipar belsô szerkezeti átalakulása és - ezzel párhuzamosan - a termelő szolgáltatások fejlődése vetíthető eló. $\mathrm{Az}$ externáliákra épitö, rugalmas termelésszervezés és a technológiai átalakulás a fejlett (üzleti-tanácsadási, kísérleti-fejlesztési) szolgáltatásokat a leggyorsabban növekvő gazdasági ágazattá emelheti. A fejlett termelö szolgáltatások területi eloszlása ma még nagyfokú koncentrációt mutat, azonban az utóbbi évtizedben - tudatos regionális politikai támogatások következtében - Franciaországban, Hollandiában, Ausztriában, az Egyesült Királyságban és Olaszországban a dekoncentráció jelei figyelhetők meg, bár az ágazatban elkezdődött európai méretú specializáció azt mutatja, hogy a centrumrégiók a megszerzett pozícióikat nehezen kívánják feladni. A decentralizáció mozgatóeröi azonban hatásosabbnak tűnnek, lévén a terjedő regionális specializáció és térbeli klaszteresedés hosszú távú versenyképességének előfeltétele a megújulást folyamatosan biztositó fejlett szolgáltatások jelenléte (Illeris 1996; Raffay 1996).

A gazdaság szervezeti rendszerét is várhatóan a jelenlegi folyamatok alakítják a jövő évszázad első évtizedeiben. A kis- és középvállalatok kétharmados súlya a gazdaságban fennmarad, a multinacionális vállalatok stratégiáinak sikerétől függően elképzelhetô arányuk lassú növekedése a feldolgozóiparban. E vállalatforma ugyanis fontos tényező a gazdasági és társadalmi kohézió erősítésében, viszonylag kis tőkeigénye miatt a fejletlenebb térségek foglalkoztatási gondjainak megoldásában továbbra is lényeges szereplö lehet, bảr a gazdaság minőségi átalakulása és a regionális versenyképesség elötérbe kerülése miatt a közepes méretű vállalkozások fejlődése és hálózatba szerveződése nagyobb ütemben halad elöre, sőt, felértékelödőben van a nagyvállalati kapcsolatok szerepe is.

Az európai növekedési, versenyképességi és foglalkoztatási feltételek alakulása szempontjából figyelembe veendő harmadik térformáló erônek a transzeurópai hálózatok fejlődése tekinthetö. A közlekedési, a telekommunikációs és energetikai hálózatok összehangolt fejlesztése Nyugat-Európában érzékelhetöen hozzájárult a versenyképesség fokozásához. Az európai perifériák - a kohéziós országok és különösképpen az Európai Unió társult kelet-európai tagállamok - hálózatos infrastruktúrái azonban ma még komoly korlátot jelentenek az európai piacok megközelítésében, a gyors információáramlásban. A perifériák felzárkózásának egyik meghatározó elöfeltétele a tranzakciós költségek mérséklése, hisz csak ezáltal aknázhatók ki az elmaradott térségek alacsony munkabéréből adódó elönyök. Éppen ezért Európa közlekedési hálózatának fejlesztésében a piacgazdaság hatékonysági kritériumain kívül regionális és szociális tényezők is érvényesülnek. Az Európai Unió transzeurópai hálózatfejlesztési tervei az elszigetelt régiók megközelíthetöségi feltételeinek javítását célozzák. 2010-ig a nagy sebességú vasútvonalak kiépitése hat órával csökkenti a perifériák megközelítési idejét, ami egyben azt is jelenti, hogy e térségek potenciális piaci kapcsolatai a mai 10-15 milliós népességủ hatókör helyett 20-40 milliós térségekre terjedhetnek ki (1. ábra). 


\section{1. ÁBRA}

Az európai tér összehuizódása

(Contraction of the European Space)
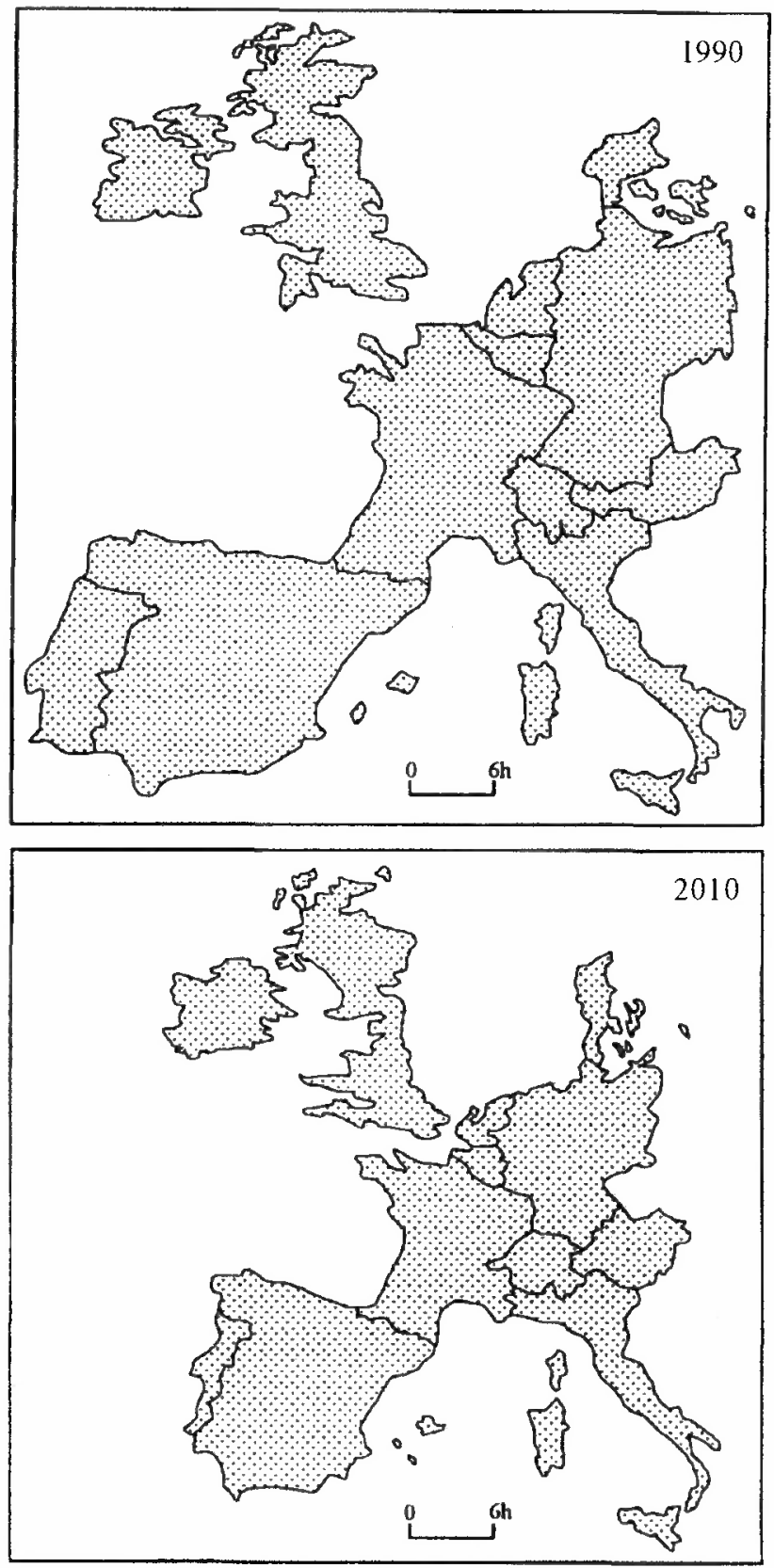

Forrás: Europe 2000+, 1994. 66. o. 
A területi fejlödést hosszú távon alakító folyamatok hatásai - miként már többször említettük - különbözőek lehetnek az egyes régiókban és településtípusokon. Az európai városoknak is újfajta kihívásokkal kell majd szembesülniük, a városhierarchia egyes szintjei között funkcionális átrendeződés játszódhat le. Foglaljuk össze röviden az európai városrendszerek várható fejlődésének legfontosabb összetevőit (Cheshire-Gordon 1995; Conti 1993; Enyedi 1996, 1997; Kunzmann-Wegener 1991).

1) A globális városok dominanciája: Európa két, transzkontinentális funkciókkal rendelkezö metropolisa, London és Párizs tovább erősíti globális piacszervezö pozícióit. Berlin jövőbeli szerepe még viszonylag bizonytalan: a város a II. világháború elötti fontosságát csak a kelet-európai térség gazdasági fellendülése révén nyerheti vissza, ami viszont csak a távolabbi jövőben várható;

2) A városrendszerek polarizálódása a nagy sebességü közlekedési infrastruktúra mentén: A transzeurópai közlekedési folyosók közelében elhelyezkedő városok növelhetik versenyképességüket. Megnö a nemzetközi repülőterek megközelíthetőségének jelentősége: a repülőterektől távoli városok lemaradnak a technológiai átalakulásban, tőkevonzó képességük gyenge marad;

3) Az államhatárok szerepének csökkenése átalakitja a városhierarchiát: az Unió magtérségeinek határ menti városai az egységes európai piac kifejezett kedvezményezettjei lettek, a német egység megteremtésével több német nagyváros új funkciókhoz jutott, fokozni tudta teljesítóképességét. A kelet-európai átalakulás egyrészt az EU-tagállamok határokhoz közeli nagyvárosait hozza elönyösebb helyzetbe, másrészt Budapest, Prága és Varsó szerezheti vissza II. világháború elötti európai pozícióit;

4) Az ipari nagyvárosok hanyatlása: Az atlanti növekedési erötérben és Európa más tradicionális iparvidékein a hagyományos feldolgozóipari központok viszszaesése tovább folytatódik: azok a városok, amelyek valamilyen ok miatt távolmaradtak a szerkezetátalakitás fỏ áramától, egyre nehezebben képesek adaptálódni a posztfordista gazdaságszervezés követelményeihez, teljesitőképességük hanyatlik, fizikai környezetük degradálódik;

5) A nagyvárosokat körülölelö rurális övezetek felértékelődése a közlekedési folyosók környékén: Az "urbánus" térségek jelentős expanzió elött állnak. Ezek lehetnek a korábbi városi ipari tevékenységek új telephelyei, alacsonyabb telekáraik és vonzó természeti környezetük miatt lakóhelyi funkciỏik bövülhetnek, a kedvező megközelítési lehetőségek révén kereskedelmi és elosztó központok telephelyeivé válhatnak.

A rurális (falusias) térségek jỏvőjét befolyásoló tényezök sorában kituntetett jelentősége van az Európai Unió közős agrárpolitikájának. Az agrártermelés támogatására ma a közösségi költségvetés közel 50\%-át fordítják, 2006-ban ennek aránya $44 \%$ alá kerül. Várható tehát, hogy az agrárreform érzékelhető hatással lesz a rurális területek fejlődésére, a gazdasági szerkezet diverzifikálódásával és a lassú elnéptelenedés folytatódásával kell számolni.

A rurális területek fejlesztésében több versenyelönyt is érdemes alaposan figyelembe venni. Ezek lehetőséget teremthetnek a gazdasági szerkezet diverzifikálására, bizonyos tevékenység telepítéséhez kedvezö feltételeket jelenthetnek (1. táblázat). 


\begin{tabular}{|c|c|c|}
\hline \multicolumn{3}{|c|}{$\begin{array}{c}\text { 1. TÁBLÁZAT } \\
\text { Versenyelönyök a rurális fejlesztésben } \\
\text { (Competitive Advantages in Rural Development) }\end{array}$} \\
\hline Fejlesztési cél & A versenyelonny jellege & Mintarégió \\
\hline Iparfejlesztés & $\begin{array}{l}\text { Jó minőségủ munkaerő és gazdasági infrast- } \\
\text { ruktúra, lakossági és üzleti szolgáltatások, } \\
\text { kedvező lakásfeltételek, jó életminöség, } \\
\text { fejlett oktatási rendszerek }\end{array}$ & $\begin{array}{l}\text { Bretagne, Bajoror- } \\
\text { szág }\end{array}$ \\
\hline Turizmus & $\begin{array}{l}\text { Kedvezỏ környezet, attraktív táj, hagyomá- } \\
\text { nyos mezógazdaság, történelmi emlékhelyek, } \\
\text { kulturális lehetőségek, fejlett vendéglátó- } \\
\text { hálózat, ủdülési, pihenési lehetőségek }\end{array}$ & $\begin{array}{l}\text { Skót-felföld, } \\
\text { Anvergne, Bajoror- } \\
\text { szág, Kréta }\end{array}$ \\
\hline Pihenés & $\begin{array}{l}\text { Nagyvárosi térségek közelsége, jó megköze- } \\
\text { líthetősége, harmonikus környezet, kulturális } \\
\text { létesítmények, szállodák, sportolási lehetö- } \\
\text { ségek }\end{array}$ & $\begin{array}{l}\text { Ardennek, nemzeti } \\
\text { parkok az Egyesült } \\
\text { Királyságban }\end{array}$ \\
\hline Ingázók lakóhelyei & $\begin{array}{l}\text { Gazdasági centrumok jó megkỏzelíthetỏsége, } \\
\text { kedvezó lakáshelyzet, olcsó telekárak, jó } \\
\text { személyi szolgáltatások }\end{array}$ & $\begin{array}{l}\text { Nagyvárosok közeli } \\
\text { rurális térségek }\end{array}$ \\
\hline $\begin{array}{l}\text { Nyugdijasok lakó- } \\
\text { helyei }\end{array}$ & $\begin{array}{l}\text { Kellemes kömyezet, olcsó lakásfenntartás, } \\
\text { lakossági és szociális szolgáltatások, fejlett } \\
\text { egészségügy, biztonságos életfeltételek }\end{array}$ & Délnyugat-Anglia \\
\hline
\end{tabular}

Forrás: Europe 2000+, 1994. 120. o.

Európa térszerkezetének távlatait ma már csak részben alakítják a nemzetállami stratégiák, a globális folyamatoknak és az ezeket jobbára figyelembe vevó közösségi politikáknak a motiváló ereje sokkal erỏsebbnek tekinthető. Nem lényegtelen tehát, hogy milyen elképzelések látnak napvilágot az egységes európai tér jövőjét illetóen.

A közösségi politikákban a tagállamok azon szándéka nyilvánul meg, hogy bizonyos feladatokat egyuittesen oldjanak meg. A közös politikák általában nem területfejlesztési jellegủek, hanem sajátos célokat szolgálnak. A Maastrichti Szerzódés azonban ủj megvilágításba helyezte a területi jellegü ágazati politikák hatásait. A Bizottság kompetenciája azért is bőviult jelentősen, mert számos fontos közősségi politika (a közös mezőgazdasági politika, a közlekedéspolitika, a transzeurópai hálózatok, a strukturális politika, a $\mathrm{K}+\mathrm{F}$, a versenypolitika és a környezeti politika) területfejlesztési célokat is szolgál.

A közösségi politikák célja, hogy egész Európa számára kedvezö legyen az európai integráció, hiszen eddig inkább a tehetősebb, már eleve kedvezỏbb helyzetben lévỏ országok profitáltak azokból. E politikák továbbfejlesztése ezért három fontos szemponton nyugszik (European Spatial Development Perspective 1997):

- A termelő tevékenységek kiegyensúlyozottabb térbeli eloszlásának elósegítése;

- a fenntartható fejlödés támogatása;

- a sajátos regionális igények fokozott figyelembevétele.

E célok megvalósításához átfogó terủleti elemzésekre van szükség: a régiók SWOT-analízisének értékelésével meg kell állapodni jelzőszámokban és kritériumokban a terủleti tipológiák kidolgozásához, és a hosszú távú európai szcenáriók vázolása szükséges. A térségi kritériumok és jelzőszámok a régiók fơldrajzi fekvése, 
gazdasági erőssége, társadalmi és térségi integrációja, területhasználati módjai, természeti potenciálja és kulturális vagyona alapján határozhatók meg.

A hosszú távú szcenáriók kidolgozásához különböző alternatív hipotéziseket kell megvizsgálni a következö területeken: a demográfiai változások, a globalizáció hatásai, a régiók alkalmazkodása az intenzifikálódó nemzetközi kereskedelemhez, a tercier szektor dominanciája, az információs társadalom kibontakozása, a közös agrárpolitika továbbfejlesztése, az Európai Unió kelet-közép-európai bỏvítése, illetve az Unió nem tagállamokhoz füződő kapcsolatának alakulása.

$\mathrm{Az}$ európai területfejlesztés három alapelvének (kiegyensúlyozott, többközpontú városrendszer, azonos hozzáférés az infrastruktúrához és a tudáshoz, a természeti és a kulturális örökség körültekintő kezelése és fejlesztése) figyelembevételével számos olyan különleges döntési lehetőség adódik, amelyeket az adott célok elérése befolyásol. Ezek megvalósításának általános követelménye, hogy területi dimenziójuk legyen (amelyek az ágazati politikák kiegészítését és integrált, sokszektorú politikai kezdeményezését jelentik), európai léptékben fogalmazódjanak meg, figyelembe vegyék a tagállamok érdekeit, és a gyakorlatban hatékonyan végrehajthatók legyenek. Az Európai Területi Fejlődés Távlatai c. dokumentum e kritériumoknak eleget tevö feladatokat határoz meg:

- Kiegyensúlyozott, többközpontú városrendszer, a város és vidéke újfajta kapcsolata

Munkamegosztás és együttmüködés a városok között (városok integrált területfejlesztési stratégiáinak támogatása, elsősorban a határon túlnyúló területeken; városhálózatok kooperációja országok közötti és európai szinten; a nemzeti/nemzetközi, illetve regionális/helyi hálózatok közötti kapcsolatok javítása; a kelet-közép-európai és a Földkőzi-tenger melléki városokkal való együttműködés erösítése). A dinamikus, vonzó és versenyképes városok fejlődésének elösegítése, a világvárosok és a kapuvárosok szerepének erösítése, elsősorban a peremterületeken; a városok vonzerejének növelése; az egyoldalú gazdasági szerkezettel rendelkező városok gazdasági alapjának diverzifikálása; a gazdaság fejlesztése rurális térségek kisvárosaiban). Fenntartható városfejlesztés (sikeres városok tapasztalatainak átvétele; a gazdasági és környezetvédelmi infrastruktúra javitása; társadalmi és funkcionális diverzitás támogatása, társadalmi kirekesztettség megakadályozása; városi ökoszisztémák intelligens kezelése, zöldövezetek védelme és fejlesztése; a városokon belüli fenntartható közlekedés támogatása). Partnerség a város és vidéke között (a vállalatok letelepítésére vonatkozó stratégiák, környezetvédelmi intézkedések érzékeny vidéki területeken, a szolgáltatások minimális színvonalának fenntartása a rurális területeken elnéptelenedésük megakadályozására; öneröre alapuló fejlödés elösegítése ezeken a területeken). A kulturális területek diverzifikációja (a gazdaságszerkezet diverzifikálása a gyenge, föleg agrárjellegü régiókban; fenntartható mezőgazdasági tevékenység és környezetvédelmi intézkedések elősegítése; megújuló energiaforrások kihasználásának elősegitése a rurális területeken).

- Azonos hozzáférés az infrastruktúrához és a tudáshoz

Jobb elérhetőség európai és interkontinentális szinten is, ami többet jelent, mint a transzeurópai hálózatok egyszerü bővítése (az infrastruktúra javítása a 
távol esö területeken is; nagyobb kikötök és repülöterek interkontinentális megközelíthetőségének javítása; az elérhetőség könnyítése hatékony tömegközlekedéssel azokon a területeken, amelyek közvetlenül nem kapcsolódnak nagyobb hálózatokhoz; a telekommunikációs létesítmények elérhetőségének javitása úgy, hogy az alapellátás minden területen hozzáférhető legyen). Az infrastruktúra hatékonyabb és fenntartható használata (a személygépkocsitól való függést mérséklö helyi politikák; a közúti közlekedés csökkentése túlzsúfolt közlekedési tengelyekben; a multinodális és a kombinált közlekedés támogatása; közös infrastruktúra használata a felesleges verseny kiküszöbölésére; a közlekedési szolgáltatások közötti kapcsolatok javítása, elsősorban a ritkán lakott területeken); innovációk és ismeretek terjesztése nemcsak mennyiségi, hanem minőségi értelemben is (az innovációs technológiák elérhetőségének biztosítása minden régió számára; technológiai transzferközpontok létesítésének támogatása, ágazatok közötti kapcsolatok javítása az elmaradottabb régiókban; a felsöoktatáshoz való minimális hozzáférés a legelmaradottabb területeken is; az oktatás és szakképzés általános szinvonalának emelése).

- A természeti és a kulturális örökség kezolése és fejlesztése

A természeti örökség megőrzése és fejlesztése (természetvédelmi területek hálózatának továbbfejlesztése, erősítése; a nagy biodiverzitású és érzékeny területek megfelelö kezelése; a gazdaságfejlesztés és a természeti örökség megőrzése szempontjainak harmonizálása; természeti katasztrófákkal veszélyeztetett térségek kockázatának csökkentésére regionális és transznacionális stratégiák kidolgozása). A vízkészletek gondos kezelése (integrált stratégiák a vízkészletek és az árvízkockázat kezelésére, a szárazságnak kitett területeken a vízellátás és a vízigény közötti egyensúly javítása, a nagyobb, elsősorban parti és transznacionális vízbázisok gondos kezelése; a túlzott vízkivétellel vagy lecsapolással veszélyeztetett nedves területek megőrzése és helyreállítása). Az európai kultúrtájak fenntartása és kreatív kezelése (kulturális és történelmi jelentőségủ tájak fenntartása a földhasználat gondos tervezésével; antropogén tevékenységtől károsodott tájak rehabilitációja; a jellegzetes tájkép fenntartása a mezögazdasági müvelés alól kivont területeken). A városi kulturális örökség megörzése és kreativ kezelése (a kulturális örökség pusztulásával sújtott területeken megelözö stratégiák alkalmazása; a városi kulturális örökség védelme a túlzott turizmus, ingatlanspekuláció és infrastruktúra-építkezések káros hatásaitól; összefüggỏ épületegyüttesek kreatív átalakítása a városkép leromlásának megakadályozására).

Az integrált területfejlesztés lényege a kiválasztott megoldási módozat koherens területfejlesztési stratégiákká való fejlesztése összeurópai, transznacionális és regionális-helyi szinten. Ehhez horizontális (multiszektorális politikára) és vertikális koordinációra is szükség van.

A politika koordinálásának szükségességét európai szinten már felismerték, elsősorban a környezetvédelmi, közlekedési, mezőgazdasági, szociális és regionális politikákban. A jövő feladata az, hogy a koordináció elvét térségi szinten is fokozottan érvényesítsék, a térségi összefogás az Európai Unió egész területén erösödjön. 
Az európai integrált területfejlesztési politika lehetséges fỏ elemei a következỏk:

- jobb térségi egyensúly, gazdasági és társadalmi kohézió,

- kiegyensúlyozottabb városi és regionális versenyképesség,

- jobb elérhetöség,

- az Európai Unió határrégióinak és azok városainak fejlesztése,

- Euro-folyosók kialakítása,

- a biodiverzitás fenntartása és fejlesztése.

Ezeknek az integrált feladatoknak a gyakorlati megvalósíthatósága ạttól függ, hogy kidolgozhatóak-e területileg integrált transznacionális stratégiák. Transznacionális megközelítést, egy térségen belül több ország részvételét igényli számos kérdés, például az òkológiai rendszerek védelme, a hálózatok kialakítása, a természeti katasztrófákkal fenyegetett régiókban a kockázatok csökkentése, a vízellátás, a rurális térségek kisvárosai helyzetének javítása stb.

$\mathrm{Az}$ integrált kezdeményezések elvét transznacionális szinten kedvezỏen fogadták és alkalmazzák is az INTERREG IIC programban. A további együttmüködés igényét jelzi, hogy az Európai Unió tagállamai hét nagy transznacionális kooperációt terveznek. Az adott régiók lehatárolása nem végleges és nem statikus, az érintett transznacionális területek mérete és alakja is rugalmas. A transznacionális politika végrehajtása végső soron regionális és helyi szinten történik. Regionális szintü intézkedéseket igényel pl. az elérhetőség javítása a közlekedési rendszerek és a nemzeti/nemzetközi csomópontok összekapcsolásával, a rurális térségek népességének megtartására tett erófeszítések, a fenntartható fejlődés és a megújuló eróforrások hasznosítására stratégiák kidolgozása, a regionális és európai jelentőségủ tájak és ökoszisztémák fejlesztése stb. Helyi szinten szervezendő feladat - többek között - a városcsoportok vagy városhálózatok gazdasági szerkezetének diverzifikálása, a fenntartható városfejlődés, a multinodális közlekedés támogatása és a közlekedési szükségletek csökkentése, a városok és a rurális térségek területfejlesztési célú partnerkapcsolatainak fejlesztése, a városi örökség megtartása és védelme érdekében hozott intézkedések stb.

Az Európai Területi Fejlődés Távlatai c. dokumentum megvalósítása ơnkéntes alapon történik. A jelenlegi tervezet hivatalos elfogadásáig három lépésre van szủkség: széles körủ politikai vitákat kell folytatni, innovatív és kísérleti lépéseket kell tenni, stabil technikai hátteret kell kialakítani.

\section{Az európai transznacionális makrorégiók fejlódési perspektivái}

Az európai integráción belüli államhatárok korlátozó erejének mérséklődése, az európai gazdasági tér intézményesített fejlesztése és az Európai Unió keleti kibővítése új megvilágításba helyezi a nemzeti határokon átnyúló régiók fejlödési lehetőségeit. A kontinens versenyképességének fokozásában a közösségi, a nemzeti és a szubnacionális kereteken kívül fontos stratégiai egységek lehetnek a jövőben az európai makrorégiók, azok a nagy teljesítóképességủ térségek, amelyek alkalmasak a méretgazdasági követelmények érvényesítésére, az integrált hálózati rendszerek nagy távlatú fejlesztésére, a hatékonyság fokozására.

Az Európai Unió stratégái az új évszázad területfejlesztési politikájának megalapozására - figyelembe véve az eddigi interregionális kapcsolatokat és fejlődési pályákat - nyolc transznacionális makrorégiót határoltak le (2.ábra, 2. táblázat), bár az új német tartományok önálló régióként való szerepeltetése vitatható, mint ahogy a társult kelet-közép-európai államok makroregionális tagolása sem megoldott. 


\section{2. ÁBRA}

Európa transznacionális régiói

(Transnational regions in Europe)

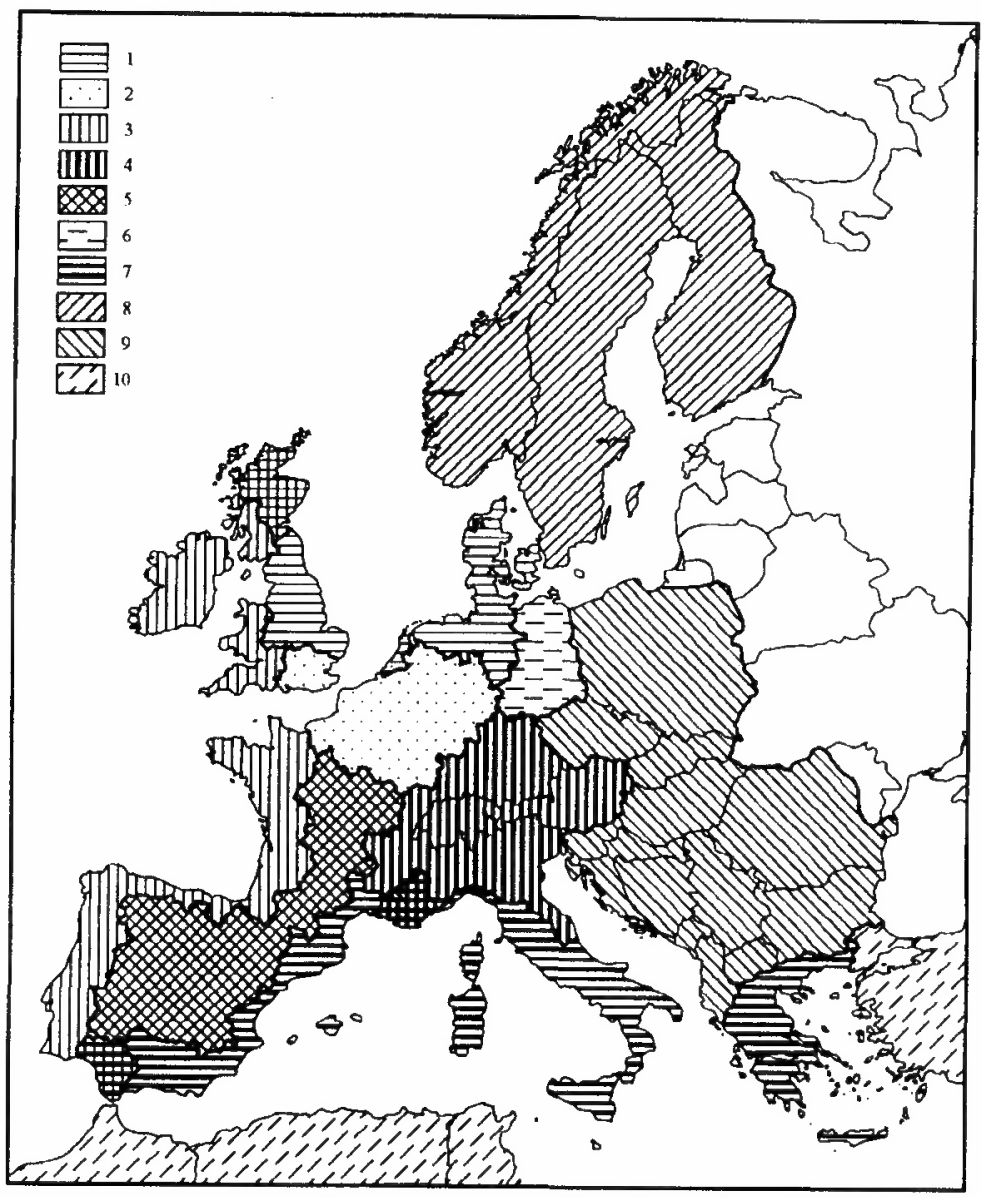

Jelmagyarázat: 1 - Északj-tengeri; 2 - központi fỏvárosi; 3 - Atlanti ív; 4 - Alpoki ív; 5 - kontinentális átlo; 6 - Kelet-Németország; 7 - Mediterráneum; 8 - ÉszakEurópa; 9 - Kelet-Közép-Európa; 10 - Dél- és Kelet-Mediterráneum.

Forrás: Európa 2000+, 1994. 170. ०. 


\section{TÁBLÁZAT}

Az európai makrorégiók föbb mutatói (1991. évi adatok alapján)

(Main Indicators of European Macro Regions, 1991)

\begin{tabular}{|c|c|c|c|c|c|c|c|c|c|}
\hline Megnevezés & 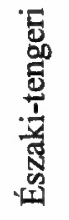 & 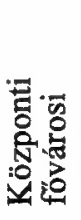 & 疍 & 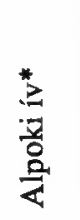 & 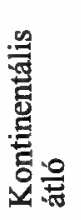 & 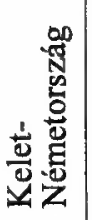 & 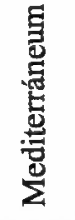 & $\underset{\widetilde{a}}{\stackrel{\sim}{\sigma}}$ & 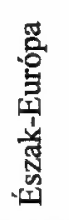 \\
\hline Terület, ezer $\mathrm{km}^{2}$ & 198 & 269 & 498 & 300 & 446 & 108 & 538 & 2361 & 1112 \\
\hline Népesség, millió fö & 46 & 90 & 48 & 55 & 21 & 19 & 69 & 348 & 18 \\
\hline Népsűrúség, fö $/ \mathrm{km}^{2}$ & 232 & 337 & 94 & 184 & 47 & 162 & 125 & 149 & 16 \\
\hline $\begin{array}{l}\text { Egy főre jutó GDP az } \\
\text { EUR12\%-ában }\end{array}$ & 99 & 116 & 80 & 122 & 87 & 33 & 74 & 100 & 120 \\
\hline \multicolumn{10}{|l|}{$\begin{array}{l}\text { Foglalkoztatotti } \\
\text { szerkezet, } \%\end{array}$} \\
\hline Agrár & 4,6 & 2,7 & 16,0 & 5,6 & 10,1 & 8,9 & 13,3 & 6,4 & 5,4 \\
\hline Ipar & 29,7 & 32,6 & 30,4 & 39,2 & 30,1 & 44,7 & 23,7 & 33,2 & 28,6 \\
\hline Szolgáltatások & 65,7 & 64,7 & 53,6 & 55,2 & 59,8 & 46,4 & 63,0 & 60,4 & 66,0 \\
\hline $\begin{array}{l}\text { Munkanélküliségi } \\
\text { ráta, \% }\end{array}$ & 8,6 & 7,6 & 10,0 & 4,6 & 10,1 & 14,1 & 16,2 & 9,4 & 12,3 \\
\hline $\begin{array}{l}\text { A Strukturális Ala- } \\
\text { pokból támogatott } \\
\text { népesség aránya, \% }\end{array}$ & 35,6 & 21,4 & 72,3 & 23,7 & 62,7 & 100,0 & 75,9 & 51,6 & 27,2 \\
\hline
\end{tabular}

Megjegyzés: *Ausztria és Svájc nélkül.

Forrás: Europe 2000+, 1994. 171 o.; Yearbook of Nordic Statistics. 1990. Különbözö oldalak.

Az Európa legfejlettebb térségének számító központi fővárosi makrorégió jövőbeli fejlöđését az Unió gazdasági és pénzügyi integrációja kedvezően befolyásolja, a nemzetközi kereskeđelem és a bankszektor hosszú ideig növekedési erőforrás marad. A pénzügyi és a kereskedelmi szolgáltatások koncentrációja a makrorégió sok nagyvárosában azonban fejlódési rendellenességeket eredményezhet, mint ahogy a versenyszféra más ágazataiban is jelentős területi átrendeződésre lehet számítani. A városhierarchia alacsonyabb szintjein elhelyezkedỏ nagyvárosok, de a kis- és középvárosok többsége is fejlett infrastruktúrájuk révén kedvező versenypozícióban maradhatnak. A magas népsürüségböl fakadó túlzsúfoltság és a marginalizálódott rétegek koncentrációja miatt e régióban egyrészt a szociális kohéziót erösítỏ programok kidolgozására kell a közösségi regionális politikának összpontosítania, másrészt a közel kilenc milliós népességet számláló depressziós körzetek revitalizálását kell megoldania.

A kontinens legperspektivikusabb fejlödési pályáján mozgó alpoki makrorégió integrált fejlesztésének egyik akadálya, hogy a térség centrumában elhelyezkedö Svájc nem tagja az Európai Uniónak. Az országhatáron átnyúló interregionális szerveződések sürü hálózata, az Alpok Konvenció egyuittmüködési programjai azonban némiképpen 
ellensúlyozzák az intézményes integráció hiányát. A makrorégió infrastrukturális ellátottságában még sok hiányosság tapasztalható, magas az éleződő versenyben kedvezőtlen helyzetbe sodródó ágazatok aránya. A hosszú távú fejlődésben azonban a térség számára új növekedési erőforrás lehet a kelet-közép-európai régió közelsége, a délkelet-európai gazdaság újjáépítésében az észak-olasz, délnémet és keletfrancia régiók fontos piacokhoz és vezetỏ szerephez juthatnak.

Az észak-európai országok alkotta harmadik legfejlettebb makrorégió koordinált fejlesztését Norvégia Unión kívül maradása lassítja. A legfontosabb kohéziós feladat a térség bekapcsolása az európai közlekedési hálózatba, fejleszteni az északi régiókat összekapcsoló gyorsforgalmú közúti és vasúti rendszereket, illetve a legészakibb területeken a népesség életkörülményeiben megteremteni az európai szintü ellátást. A skandináv országok motorikus szerepet játszanak a Balti-tenger környéki régiók és nem EU-tagállamok gazdasági kapcsolatainak erősítésében. A Balti-tenger környékének közös stratégiája részletes elképzeléseket tartalmaz e térség közlekedési, környezeti, településhálózati és gazdasági viszonyainak a fejlesztésére (VASAB 1994).

$\mathrm{Az}$ átlagos teljesítóképességủ északi-tengeri makrorégió az angol és a skót iparvidékeket, Északkelet-Hollandiát, Észak-Németország konurbációs térségeit és Dániát foglalja magába. A diverzifikált térszerkezet ellenére számos azonos fejlesztési problémakör rajzolódik ki. Az Európai Unió által támogatott hanyatló ipari térségekben 15 millió lakos él. A hagyományos iparágak leépülése tovább tart, a hadiipari megrendelések csökkenése és az állami szféra kiadásainak mérséklése miatt e makrorégió depressziós vonásai még hosszú ideig fennmaradnak. A fejlesztések fỏ irányai a szerkezetátalakulás tipikus megoldású módozataihoz kapcsolódnak: meg kell erősíteni az üzleti szolgáltatásokat és a $\mathrm{K}+\mathrm{F}$ kapacitásokat, a térségen belüli alrégiók kooperációját szolgáló hálózatokat.

A kontinentális átlónak nevezett makrorégió az Unió legdifferenciáltabb nagytérsége. Madrid, Toulouse és Orleans térsége magas urbanizációs értékeket mutat, több kiterjedt francia és spanyol rurális övezetben fejlett, szolgáltató jellegủ központok (Dijon, Tours, Clermont-Ferrand, Limoges, Zaragoza, Valladolid) találhatók, míg végül hét millió lakos olyan falusias térségekben él, amelyek városhálózata nem képes a megfelelỏ szolgáltatások ellátására. A fejlödési trendek azt jelzik, hogy folytatódik e térség differenciálódása, az alacsony népsürüségủ területek közlekedési infrastruktúrájának fejlesztése elött sincs különösebb perspektíva, a gyenge szerkezetủ rurális területeken a népesség tovább csökken. A nagyvárosi térségek diverzifikált fejlesztésén kívül meghatározó stratégiai program a kis- és középvárosok szolgáltatásfejlesztésének támogatása új kommunikációs technológiák bevezetésével és vállalkozásfejlesztési centrumok létesítésével.

Az atlanti ív az Unió nagy kiterjedésü, ritkább benépesültségủ makrorégiója. A régió nagy népességtömörülései (Lisszabon, Porto, Bilbao, Bordeaux, Nantes, Cardiff, Dublin, Glasgow) az atlanti tengerparton találhatók, a köztes és a mögöttes területek városhálózata viszonylag gyenge. Az út-, vasút- és légiközlekedési vonalak ritkák, alkalmatlanok a transzeurópai hálózatba való bekapcsolódásra. A spanyol és a brit rész ipari központjainak jövője bizonytalan, várható a feldolgozóipar további hanyatlása. A rurális háttérterületek agrárgazdaságainak fejlesztéséhez nagy tökebefektetések szükségesek. A térséget érintő közlekedési beruházások és a nagyvárosok aktív technoló- 
giafejlesztési törekvései azonban ellensúlyozhatják a visszaesést. A makrorégió hosszú távú fejlesztési stratégiája ezért a korszerü termelési rendszereket alkalmazó ipari terek kiépítését és a minőségi rurális turizmus meghonositását tüzi ki alapcélul.

A transznacionális fejlesztési térségek rendszerében a mediterrán övezetnek van a legnagyobb kiterjedése, ez a második legnépesebb körzet. A 12 NUTS II. régióból és Görögországból álló térség teljesítőképessége nem éri el az Unió átlagának kétharmadát. A jövedelmek eloszlása azonban nagy különbségeket mutat. Az e régióhoz tartozó Mezziogiornón kívüli olasz és a francia régiókban az egy fơre jutó GDP az uniós átlag 100-117\%-a, míg Andalúziában, a dél-olasz régiókban és Görögországban 50-60\%. A régió településszerkezetében domináns helyet foglalnak el a többmilliós nagyvárosi agglomerációk (Barcelona, Marseilles, Róma, Nápoly, Athén, Thesszaloniki), a 30 százezer fö feletti középváros nagy része nem alkalmas nagytérségi integrátori funkciók ellátására. A népesség kétharmada elmaradott - jórészt rurális - térségekben él. A makrorégió hosszú távon is megörzi periférikus vonásait, európai léptékü növekedési központszerepet a fövárosok, Barcelona és Firenze tölthet be, elsösorban az alpoki térséggel kiépítendö kapcsolatok intenzitásától függően.

\section{A regionális politika új súlypontjai}

Az európai gazdaság fejlődési tényezőiben bekövetkezett tartós átalakulási tendenciák és az európai integráció minőségi jellegủ változásai, illetve mindezeknek a nemzeti politikai rendszerekre gyakorolt hatásai érezhetően befolyásolják a regionális politika cél-, eszköz- és intézményrendszerének jövőbeli alakulását is. A regionális fejlesztés és a makropolitika kölcsönkapcsolataiban és a regionális politika belső mechanizmusaiban jelentős átalakulásnak lehetünk tanúi.

A regionális politika évszázados fejlődésének legfontosabb tanulsága ma már az európai gondolkodás szerves részévé vált. A szolidaritás eszméjét az európai államok többségének nemzeti és ágazati politikái, az Európai Unió kohéziós stratégiája a társadalmi cselekvés kiinduló pontjának tekintik. Az európai modellt mindenekelőtt ez kủlönbözteti meg a többi kontinens társadalomirányítási gyakorlatától. A kohéziós modell gazdasági értelemben a régiók és a társadalmi csoportok közti különbségek mérséklését jelenti, azt, hogy a népesség minél szélesebb rétegei müködhessenek közre a gazdasági növekedés feltételeinek megteremtésében és részesedhessenek ezek eredményeiből. A kohézió szociális dimenziója a foglalkoztatottság lehető legmagasabb szinten tartását, a hátrányos társadalmi rétegek foglalkoztatási lehetőségeinek javítását és a munkanélküliség mérséklését fogja át. S végül a kohézió a politikai gyakorlatban az államon és az Európai Közösségen belüli kölcsönös támogatás megnyilvánulása, nem egyszerüen csupán jövedelemtranszfer formájában, hanem a belsö erőforrások optimális hasznosítását szolgáló eszközök és módszerek közös alkalmazásában.

Az utóbbi évek változásai azt vetítik elöre, hogy az új évszázad legelején a regionális politika mozgásterét - a gazdaság fejlödési öntörvényein kívül - két markáns tényező határozza meg: az egyik az Európai Unió szervezeti, müködési, finanszírozási reformja és keleti bövülése, a másik pedig - nem kis mértékben az elöbbi tényezö hatására - a nemzetállamokon belüli új hatalmi munkamegosztás kialakulása, a decentralizáció. 
Az uniós reformok azért érdemelnek különös figyelmet, mert - mint láthattuk - az európai kohézió erősítésében az integráció strukturális és kohéziós alapjaiból a régiók nagyságrendekkel nagyobb támogatásban részesülnek, mint a nemzeti regionális forrásokból. A regionális fejlesztésekre eddig felhasznált, hozzávetőlegesen 250 milliárd ECU közösségi támogatás végeredménye nem túlzottan kecsegtetö, hiszen a kohéziós elemzések a területi különbségek igen lassú csökkenéséröl tanúskodnak. A hatékonysági követelmények gyenge érvényesülésének egyik oka a támogatások szétaprózottságában keresendö. Az elökészületben lévő reformok egyik meghatározó iránya nem véletlenül az eröforrások koncentrált felhasználásának fokozása. A kedvezményezett térségek lehatárolásában a rászorultságot szigorú kritériumok alapján kell megfogalmazni, a támogatható népesség aránya a közösségi lakosságszám egyharmadára szorítandó. Az eddigi beruházási gyakorlat is felülvizsgálatra szorul, lévén a fejlesztések multiplikátor hatásai nem érték el a kívánatos mértéket, illetve - különböző okok miatt - a régiók abszorpciós képessége sem alakult az eredeti elképzeléseknek megfelelỏen. Az addicionalitás - a helyi, regionális és nemzeti hozzájárulás - következetes érvényesítése tünik az egyetlen járható útnak. A másik kulcskérdés a területfejlesztési szereplök közötti együttmüködésnek, a partnerségnek a szubszidiaritás elveit figyelembe vevö érvényesitése. Az Európai Unió támogatási rendszerében a "cost-benefit" hatások "ex ante" értékelése nagyobb szerephez jut, ami - a regionális gazdaság müködéséröl meglévő tudás és nem kizárólag a tớkeerösség függvényében - új differenciálódást indíthat el az európai régiók között.

A decentralizáció - az utóbbi évtizedek folyamatai egyértelmúen ezt mutatják ma már általános jelenségnek számít Európában. 1950-ben még a kontinens népességének negyede, a 90 -es évek közepén pedig már $60 \%$-a élt föderalizált vagy regionalizált államokban. A jövő század első évtizedének végére - a Szovjetunió utódállamait nem számítva - Európa népességének több mint kétharmada lakik majd olyan országokban, ahol a gazdasági növekedés tényezőinek befolyásolásában nem az állam, hanem a szubnacionális szint játssza a meghatározó szerepet. E mennyiségi változást - jelenlegi ismereteink szerint - két nagy népességú ország, az Egyesült Királyság és Lengyelország új regionális közigazgatásának kiépítése eredményezi majd.

A nemzetállam alapvető érdeke lesz a jövöben, hogy a gazdaságpolitika irányítása feletti hatalmát a külső - globalizációs és integrációs - nyomás hatásától az országhatárokon belüli döntési potenciál növelésével, a régiók szabályozott érdekérvényesítö képességének fokozásával kisérelje meg ellensúlyozni. A keynesiánus gazdaságpolitika tradicionális regionális fejlesztési gyakorlata az új paradigmában már nem alkalmazható sikeresen, az állami regionális politikát a régiók saját politikája váltja majd fel. E paradigmaváltás azonban nem következhet be automatikusan, a különböző fejlettségü régiók érdekeltsége a regionalizmus intézményesitésében jelentös eltéréseket mutat. A legszegényebb régiók továbbra is a külsỏ - nemzetközi és nemzeti - segítségtől remélhetik felemelkedésüket, motivációik inkább kötödnek a hagyományos támogatási rendszerekhez, mint a "Régiók Európájá"-ban kivívandó szélesebb körü autonómiához. A regionális decentralizáció elkötelezett hívei a fejlett régiók sorából kerülnek ki, amelyek az egységes piac, a gazdasági és a monetáris unió egyértelmủ kedvezményezettjei lesznek. Nem véletlen, hogy ma Európa 
leghatékonyabban regionális együttmüködési hálózatának a - területileg nem is érintkezö - Baden Württemberg, Lombardia, Rhône-Alpok és Katalónia alkotta "Európa négy motorja" elnevezésủ kooperációt tekintik (Amin-Tomaney 1995; Späth 1991).

A regionalizmus általános érvényủ kibontakozása előtt azonban még jelentős akadályok húzódnak. A nemzeti kormányok továbbra is fontos szabályozó szerepet játszanak a régiók és az Európai Bizottság közötti kapcsolatok alakításában. Európa legfejletlenebb régiói érdekeiket kevésbé tudják az integrációs döntésekben érvényesíteni, hisz a szegény államoknak egyébként is kevesebb képviselöjük van az Unió testületeiben. Az Unió versenypolitikája is a centralizációs hatásokat erősíti. A közösségi regionális politika a versenyadottságokból fakadó különbségeket kevésbé képes ellensúlyozni. A föderalista Németország az érzékletes példája annak, hogy a regionalizmus és a területi különbségek mérséklése a központi kormányzat szintjén is összeegyeztethetö.

Az európai integráció visszafordíthatatlan elmélyülésével párhuzamosan a nemzeti kormányok kulcspozíciói legalább három területen továbbra is megmaradnak. Az egyik meghatározó nemzetállami feladat a részvénytársasági kapitalizmus irányításának szabályozása. Az iparfejlesztések a jövőben sem képzelhetők el hatékony nemzeti pénzügyi rendszerek nélkül, mint ahogy a vállalati stratégiák legbiztosabb kiindulópontját is a hazai piacok és szabályozási környezet jelenti majd. A másik fontos központi kormányzati teendő a nemzeti innovációs, müszaki fejlesztési programok koordinálása marad. Végül a harmadik nemzeti szintü prioritásként a munkaerőpiaci és iparpolitikai feladatok fogalmazhatók meg. E két utóbbi nemzeti funkció gyakorlásának eredményessége azonban nagyban függ attól is, hogy számos részfeladat megoldásában a szubnacionális közigazgatás milyen hatékonysággal tud szerepet vállalni. A regionalizáció tehát a nemzetállam sikeres müködésének egyben előfeltétele is, hiszen makropolitikai célok átgondolt humáneröforrás-, oktatás-, képzés-, vállalkozásfejlesztés nélkül nem valósíthatók meg, kiegyensúlyozott piaci verseny sem képzelhető el a szociális partnerek együttmúködése nélkül. Ezek megoldása pedig a régiók szintjén a legoptimálisabb (Esterbauer 1992; Keating 1998).

Kelet-Közép-Európában az állam és a régiók közti hatalommegosztás jövője ma még bizonytalannak tủnik. A decentralizáció perspektívái a gazdasági hatékonyság és a felülröl vezérelt rendszerváltozás eredményességének összhangjától fủggnek. A hatalom telepitésének regionális elöfeltételei kedvezőtlenek. A volt tervgazdaságokban az erős központosítás szervezeti keretei fennmaradtak, még ha a központi irányítás tartalma jelentősen meg is változott. A legkedvezöbb esetben is hosszú decentralizációs folyamatra lehet számítani. Lengyelország - és talán Magyarország építi ki az európai uniós csatlakozásig a decentralizált hatalomgyakorlás politikai és intézményi kereteit.

A decentralizáció három lehetséges pályája képzelhető el Kelet-Közép-Európában. Az egyes változatok a hatalommegosztás mértékében és minöségében különböznek egymástól. Az alternatívák közüli választás természetesen nem önkényes, az egyes országok történelmi hagyományai, a gazdasági átalakulás jellege, a piacgazdasági intézmények kiépítettsége, a politikai eröviszonyok és a térszerkezet tagoltsága egyaránt befolyással vannak a hatalmi koncentráció mérséklésére. A központi államigazgatásra nehezedő decentralizációs nyomás nyilván erösebb azokban az országokban, 
ahol dinamikus regionális nagyvárosi központok (pl. Lengyelországban) autonóm fejlődésuket, az európai területi munkamegosztásba való betagolódásukat a belső erőforrásaik lehető legszabadabb hasznosításával es a posztindusztriális fejlesztési tényezők segítségével kívánják ösztönözni. Nagyobb ellenállásba ütközik az alulról jövő̉ kezdeményezések legitimálása viszont ott (pl. Magyarországon), ahol a centrumtérségnek domináns, söt erösödö pozíciói vannak a versenyképességet nőveló termelési tényezởkben. Bár e két ország példája annak érzékeltetésére is alkalmas, hogy az utő̉képessé tehető regionális centrumok megléte csupán potenciális előny, a magyar területi ónkormányzatok politikai legitimitásából és a regionális fejlesztés törvényi szabályozásából fakadó decentralizációs szivóhatás némiképpen ellensúlyozhatja az európai léptékủ markáns regionális kởzpontok hiányát.

$\mathrm{Az}$ első lehetséges decentralizációs modellben a központi és a regionális szervek kðzzti munkamegosztást világos és egyértelmü szabályok rendezik. A két szervtípus hatáskőrébe tartozó fejlesztési feladatok aszerint különülnek el, hogy azok hatása milyen területi egységre terjed ki. E feladatok megoldásához a regionális hatóságok saját bevételekkel is rendelkeznek, széles körủ tervezési jogosítványaik vannak, a hatókörükbe tartozó önkormányzatok fejlesztéseit saját pénzalapjaikból támogathatják. A régiók gazdasági fejlettségének fulggvényében a saját és a megosztott bevételek kőzponti pénzügyi transzferekkel kiegészithetők. E stratégia biztositja a legteljesebb decentralizációt, hosszú távon ez a leghatékonyabb megoldás, megvalósításához azonban számtalan - politikai, alkotmányos, közigazgatási, gazdasági elöfeltétel szuikséges. A regionális onnkormányzatok kiépülése Kelet-KözépEurópában ma még nem tünik reális perspektivának. A térség további differenciálódását idézi majd elő, hogy Lengyelország és vélhetően Magyarország a regionalizmus útjára lép.

A második decentralizációs stratégia lényege az, hogy a központból csak bizonyos - tervezési, fejlesztési, végrehajtási, felügyeleti, finanszirozási - funkciók települnek át a régiókhoz, a regionális politikai feladatok egy része továbbra is a központi hatalom kompetenciájába tartozik. A hatalommegosztás mértéke azon múlik, hogy milyen feladatok decentralizálására kerül sor, milyen intézményrendszer fogadja ezeket, és milyen eszközök állnak a régiók rendelkezésére. Az unitárius berendezkedésủ országok számára ez a változat (rövid távon) kedvezőbb, hisz a befogadó kðzeg felkészitése kisebb erőfeszítéseket igényel, a kőzigazgatási rendszer gyökeres átalakítására sincs szükség, ső́t - ami a legfontosabb - a központi szervek tényleges befolyása sem változik, a dekoncentrált állami szervezeteken keresztül a regionális fejlesztések irányítása komplexebb lesz, esetleg hatékonyságuk is nỏ.

A harmadik változatban a központi és a területi szervek közőtti felelősségmegosztás meghatározott eseti feladatok megoldására vonatkozik. A periférikus, elmaradott régiók fejlesztésére közös irányitó testületet hoznak létre, az állam pénzugyi forrásainak egy részét e döntési fórum rendelkezésére bocsátja, a fejlesztési programok megvalósítását a területi egységekre bízza. Ez a megoldás a decentralizáció legenyhébb változatát jelenti, a kialakult hatalmi berendezkedés átalakítására nincs szükség. Nem véletlen, hogy a legtöbb kelet-közép-európai ország e stratégia alapján kezdett hozzá teruletfejlesztési programjainak a kidolgozásához. 


\section{Az új századelö kihívásai Magyarországon: decentralizáció és integ- ráció}

Az új magyar területi stratégiának és regionális politikának egyrészt érvényesítenie kell a piacgazdaság követelményeit, másrészt adaptálnia célszerü az Európai Uniónak és tagállamainak a regionális politika harmonizálására megfogalmazott célkitüzéseit, végül hasznosítania érdemes a globális európai folyamatok általános tapasztalatait, többek között az interregionális és határ menti együttműködések kohéziós szerepének felértékelődését, az európai együttmúködés irányításának decentralizálódását, a regionális hatalom fokozatos funkcióbóvülését.

A gazdasági növekedés hosszú távú pályáját alakító és a térstruktúrákra is jelentős hatást gyakorló gazdasági szerkezeti átalakulás főbb elemei a következők:

- Dezindusztrializáció (az ipar lassú térvesztése, minőségi átalakulása, előbb a foglalkoztatottak számának, majd a GDP elóállításához való közvetlen hozzájárulás mértékének a csökkenése, a tradicionális ipar térvesztését az újraiparosítás mérsékelheti);

- Tercierizáció (a szolgáltatóipar túlsúlyba kerülése a gyáriparral szemben, a termelési szolgáltatások elterjedése; a gazdasági versenyben fokozódik az innovációs és a nem árjellegủ tényezők befolyása, a termék- és piaci diverzifikáció fokozódik; ez a változás a termelés és a szolgáltatások kooperációjának az erösítését indukálja);

- Technológiai váltás (az új ipari fejlődési szakaszban a vállalkozások számára nem elsósorban az anyagi jellegú input-output kapcsolatok, hanem az új technológiai elónyöket hasznosítani képes, a piaci fejlődést ösztönző technológiai, információs és pénzủgyi erőforrások válnak meghatározó tényezövé; a fenntartható fejlỏdés a technológiai képességek gyökeres megváltoztatásával képzelhetó csak el);

- Decentralizáció (a vállalati szervezet- és tulajdonformák átalakulása, az új dinamikus hajtóerók és az infrastruktủra fejlödése a gazdaság térbeli telepitését diszperzebbé teszi, regionális gazdasági hálózatok jönnek létre, egyszersmind erösödik a településtípusok közötti differenciálódás és fokozódik a verseny a gazdaság telepítéséért);

- Az európai integráció elmélyülése (A nemzetközi tőkepiacon lezajlott változások eltérỏ módon érintették a régiókat. A hálózatos gazdaságok szervezéséhez alkalmazkodni képes régiók nyertesei, a tradicionális tókeimportórök pedig vesztesei lettek a tỏke- és valutaliberalizációs változásoknak. Mivel a globalizálódó gazdaságban a vállalati központok kituintetett pozíciója továbbra is fennmaradt - sót bizonyos mértékig még erösödött - e változási tendenciák a fejlett régióknak kedveztek. Az egységes európai piac hatásai a regionális versenyképesség feltételeit új megvilágításba helyezték. Az európai növekedési erỏközponthoz geográfiailag közelebb fekvő, ahhoz fizikai infrastrukturális rendszerekkel is kapcsolódó térségek viszonylag könnyen adaptálódtak az új feltételekhez, a perifériák viszont egyértelmüen versenyhátrányba kerültek);

- A fenntartható fejlödés követelményei (a gazdasági növekedés és a környezetterhelés mérséklésének összekapcsolása, a környezetvédelmi iparágak és beruházások priorizálása). 
Tér és Társadalom, 12. 1998. 3. 1-26. p.

A regionális fejlỏdés magyarországi elemeinek változataiból két forgatókönyv állítható össze, amelyek alapvetően a területi egyenlötlenségek szerint különböznek egymástól (Enyedi 1994a, 1996).

A közepesen koncentrált forgatókönyv azon a feltételezésen alapul, hogy a további polarizálódás a kilencvenes évek végétől megállítható, ugyanakkor az ország mára kialakult területi szerkezetében nem prognosztizál alapvetően pozitív strukturális változásokat. A dekoncentrált forgatókönyv azt feltételezi, hogy a jövöben az ország mára kialakult telepuleśshálózati, térségi aránytalanságai, feszültségei lényegesen mérséklődhetnek. Emögött az a prognózis áll, hogy az újrainduló gazdasági növekedés Nyugat-Európához való felzárkózást indíthat el. Ehhez különösen kedvezỏ körülmények szükségesek: megújuló európai konjunktúra, EU-tagság, s ennek következtében jelentös területfejlesztési támogatás, a kelet-ázsiai tökebefektetök megjelenése, számottevő piacbỏvülés.

A regionális fejlődést befolyásoló tényezők alapján megrajzolható az új század első évtizedének végére kialakítandó optimális térszerkezet, megfogalmazhatók az ennek eléréséhez szükséges feladatok. A jövökép vázolásához a korábban említett folyamatokon kívül célszerú figyelembe venni az európai integráció várható hatásait is: egyrészt az európai tér kohéziójának erösítését szolgáló programok várható hatásait (Europe 2000+, European Spatial Development Perspective, CADSES Vision Planet), másrészt a magyar EU-tagsággal járó strukturális támogatások jelentös forrásnövelö szerepét. E szempontokat érvényesítendö az Országos Területfejlesztési Koncepció alapján megfogalmazható az ország térszerkezetének kivánatos textúrája, az ezt alkotó elemek kapcsolódási pontjai a közép-európai régiókkal és az európai területi munkamegosztás különbözö egységeivel (3. táblảzat).

A magyar gazdaság területi jövedelemtermelö-képességének markáns különbségeit jelentős részben az ipari termelés regionális eltérései okozzák. Az iparvállalatok szervezeti átalakulása, privatizációja, a külföldi tőke közremüködése, a vállalati versenyképesség, az exportpotenciál éles differenciákat mutat az ország magterületei (Budapest és Észak-Dunántúl) és perifériái (Alföld, Dél-Dunántúl) között. A történelmi iparvidékeken a dezindusztrializáció tartós szerkezeti válságot generált. Néhány régióban a sikeres ipari újjászervezés nem átgondolt fejlesztési stratégia, hanem nagyrészt multinacionális nagyvállalatok egyedi döntései alapján zajlik.

A magyar iparpolitika mindeddig nem fogalmazott meg regionális prioritásokat, elveket. Az iparpolitika regionális metszete természetesen nem a tervgazdaság telepitéspolitikájának a felelevenitését jelenti, hanem:

- egyrészt olyan eszközrendszer alkalmazását, amely lehetóvé teszi, hogy a versenyképes ipari termelés különbözö feltételei (innovációfejlesztés, képzett munkaeró, a termékértékesítés korszerü eszközei, müszaki infrastruktúra stb.) az egyes régiókban rendelkezésre álljanak, az ipar egy térség erőforrásait mozgósíthassa, multiplikátor hatásai érvényesülhessenek;

- másrészt olyan intézményrendszer kiépítését foglalja magába, amely képes az általános iparfejlesztési célokat közvetíteni és a regionális sajátosságok alapján azokat megvalósítani;

- harmadrészt olyan szervezési elvek és módszerek alkalmazását foglalja magába, amelyek a belsỏ regionális erőforrások komplex hasznositását, a területfejlesztés szereplöinek összehangolását, az új iparszervezési elvek (a hálózatos gazdaság és a klaszterizáció) érvényesítését célozzák. 


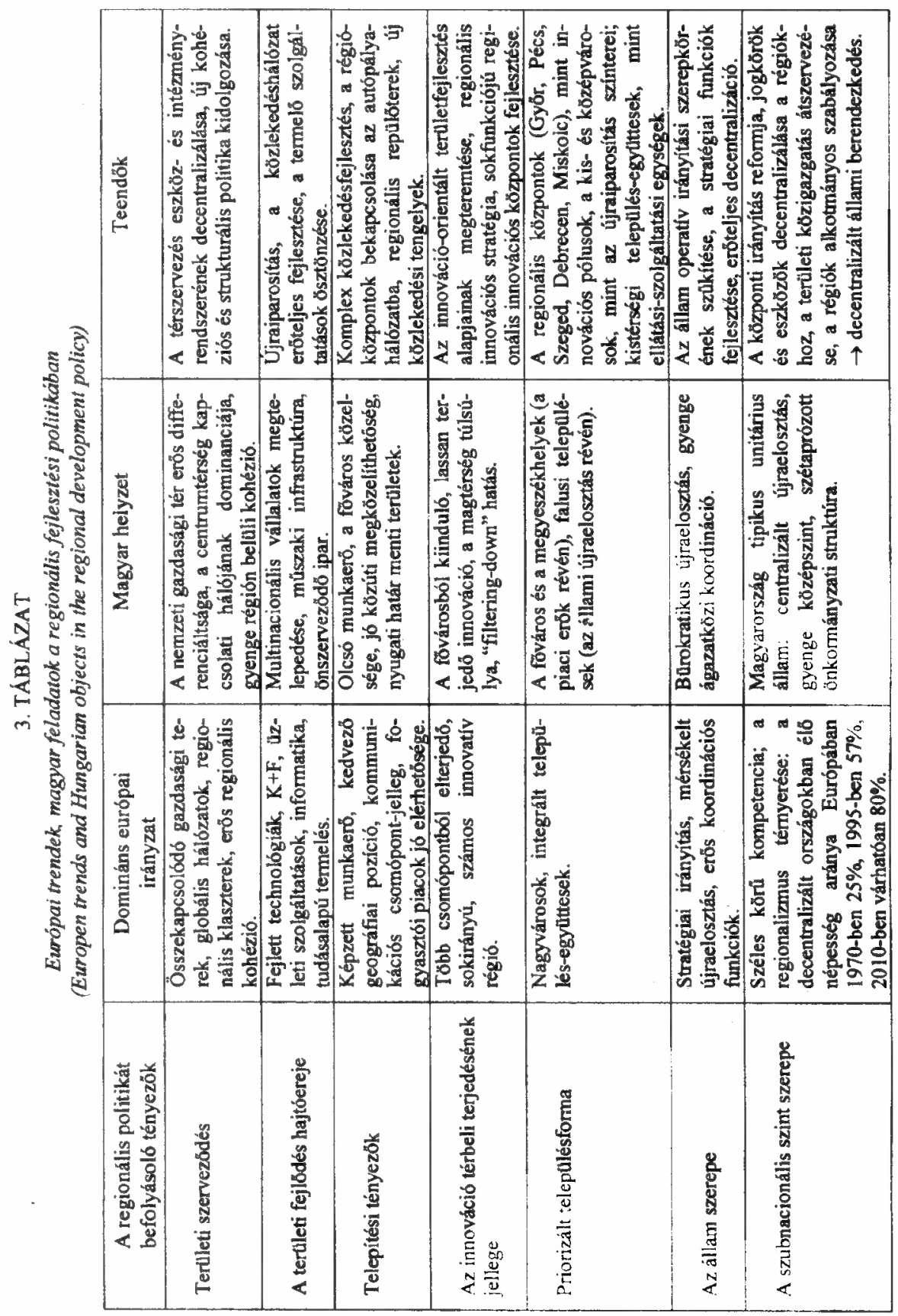




\begin{tabular}{|c|c|c|c|c|}
\hline 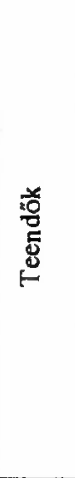 & 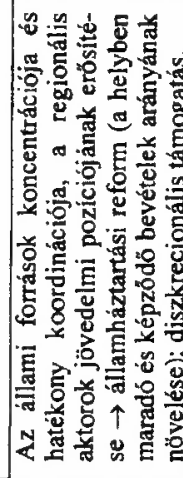 & 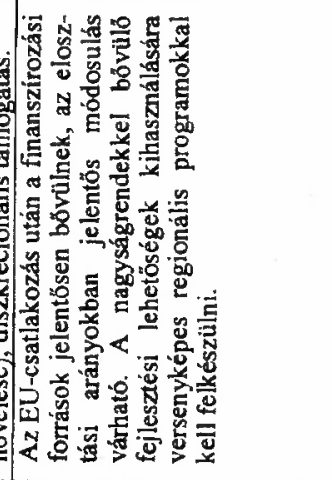 & 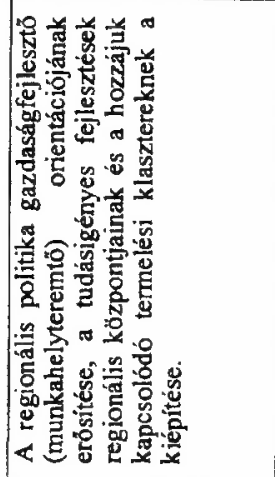 & 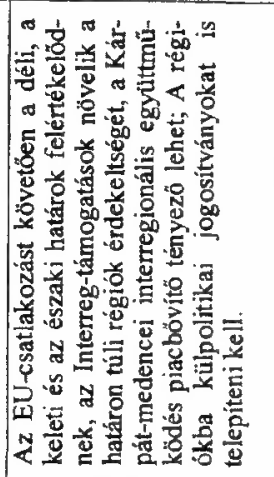 \\
\hline 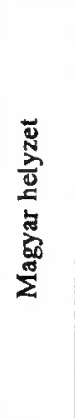 & 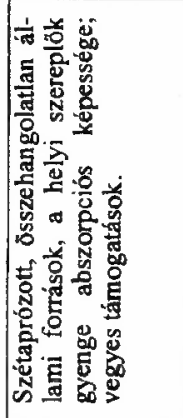 & 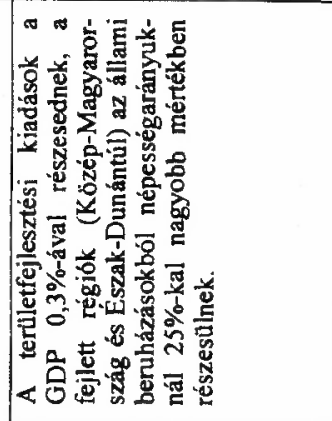 & 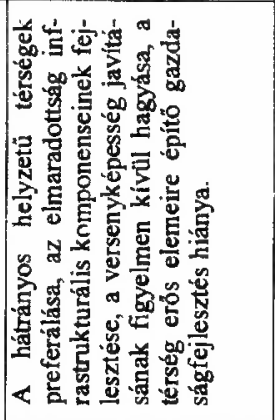 & 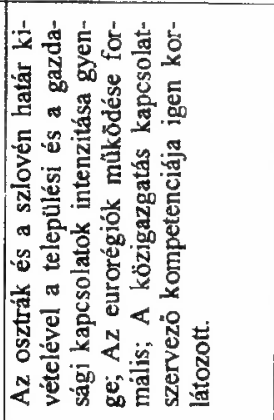 \\
\hline 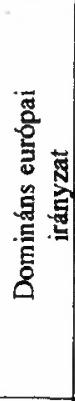 & 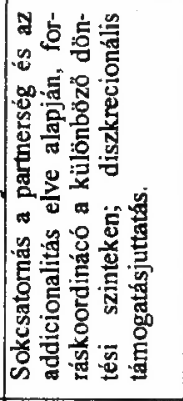 & 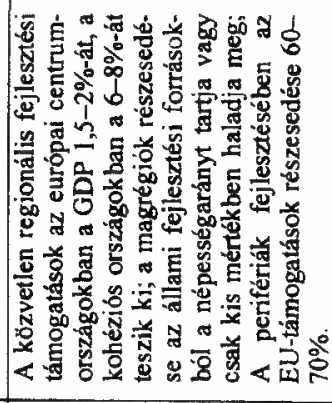 & 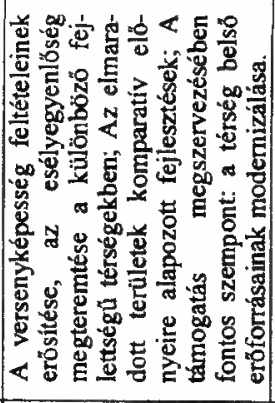 & 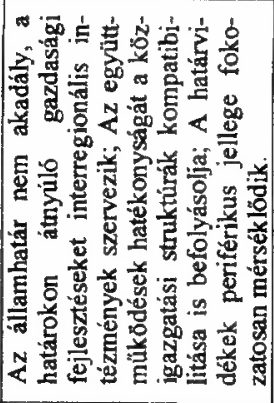 \\
\hline 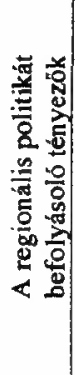 & 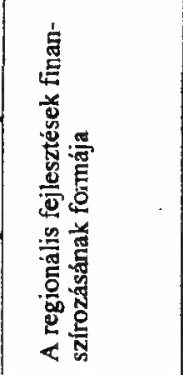 & 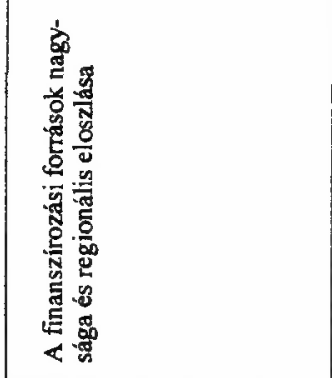 & 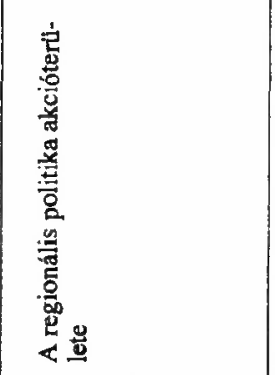 & 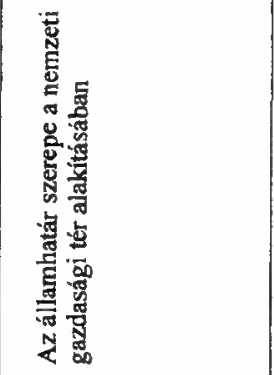 \\
\hline
\end{tabular}


A regionális iparpolitikának ez a decentralizált felfogása, a területfejlesztési programokba való szerves beágyazottsága érvényesül ma az Európai Unió tagállamaiban, ezt a felfogást ösztönzik az Európai Unió regionális és strukturális politikai támogatásai is. Míg Magyarországon a kilencvenes évtizedben az egyébként szinte elenyésző területfejlesztési támogatások $30 \%$-a szolgálta a munkahelyteremtést (s becslésünk szerint ennek csupán fele-harmada volt ipari jellegü), NyugatEurópában a közösségi strukturális alapok 30-50\%-át fordítják termelésfejlesztésre és 25-40\%-át pedig jórészt az előbbi tevékenységhez kapcsolódó humánerőforrásfejlesztésre. Az Európai Unió tagállamainak regionális fejlesztési szervezeti (köztestületek, ügynökségek, fejlesztési társulások stb.) hosszú és középtávú iparpolitikai elképzeléseket is tartalmazó regionális fejlesztési stratégiákat és koncepciókat valósitanak meg, Magyarországon a területfejlesztési és -rendezési törvény után létrejött "decentralizált" intézmények (a kötelezően megszervezett megyei területfejlesztési tanácsok és az önkéntesen szerveződô regionális fejlesztési tanácsok) pillanatnyi csoportérdekek alapján döntenek. Az EU Bizottságának Magyarországról készült jelentése - elismerve a regionális politikában tett eröfeszítéseket - is kritikusan szól a regionális intézményrendszer kialakulatlanságáról, a gyenge ágazatközi koordinációról és az erőtlen regionális politikai eszközökröl.

Az elöcsatlakozás időszakában Magyarországon is meg kell alapozni - a területfejlesztési törvény, az Országos Területfejlesztési Koncepció szellemében, az Európai Unió Strukturális Alapjai felhasználásának követelményeit figyelembe véve - a regionális iparpolitika cél-, eszköz- és intézményrendszerét, a Nemzeti Fejlesztési Terv regionális fejezeteit.

Magyarország térszerkezetének jövője alapvetően azon múlik, hogy az integrációs csatlakozás utáni új források felhasználásában milyen decentralizációs stratégiát követ majd az ország. Miként már említettük, Magyarország számára a teljes decentralizáció kínálja a leghatékonyabb megoldást. E modell alkalmazásának kulcskérdése a széles körủ autonómiával rendelkező, választott testületek által irányított közigazgatási régiók kialakitása. Régiókra Magyarországon azért lesz szükség, mert az európai területfejlesztés gyakorlata egyértelmúen bizonyította, hogy a körülbelül 1,5-2,0 millió fös népességet felölelö, önkormányzati elvek alapján irányított szubnacionális szint, a régió gazdasági kapacitásai és strukturális adottságai folytán:

- a gazdaságfejlesztési orientációjú regionális fejlesztési politika érvényesítésének optimális térbeli kerete,

- a posztindusztriális térszervező erők müködésének és ezek kölcsönkapcsolatai fejlesztésének megfelelö terepe,

- az érdekérvényesítés fontos színtere,

- a regionális politika modern infrastruktúrájának és professzionális szervezötervező-végrehajtó apparátusának kiépítéséhez a legmegfelelőbb méretủ térbeli egység,

- az Európai Unió regionális és kohéziós politikai döntési rendszerének meghatározó eleme. 
A decentralizált (vagy regionális) államszervezeti rendszer szerves fejlődéssel, komplex jogi szabályozás nyomán alakulhat ki. Az ennek elöfeltételeit megteremtö elveket az alkotmányban célszerü rögzíteni, nevezetesen:

1) Az állam fejlesztő tevékenységében, gazdaságpolitikájában épít a területi adottságok, lehetőségek és a térelemek közti kölcsönkapcsolatokra és törvényszerủségekre, ezek hasznosítása révén a társadalmi alapfunkciók gyakorlásához biztosítja a szükséges feltételeket;

2) Az állam a társadalmi méltányosság és igazságosság elvét érvényesítve saját eszközeivel közremüködik az életkörülményekben megmutatkozó objektív területi különbségek mérséklésében;

3) Az állam aktív regionális politikája emellett elösegíti a gazdasági tevékenységek és funkciók területi decentralizálását;

4) Az állam regionális politikai feladatait és eszközeit megosztja az önkormányzatokkal, a területi koordinációs jogosítványokat a területi és regionális önkormányzatokhoz delegálja.

A regionális önkormányzat intézményi struktúrájára több alternatíva képzelhetö el. A lehetséges változatok közüli választást az befolyásolja, hogy milyen alkotmányos pozíciókat szán a politikai döntéshozó a régióknak: korlátozott, meghatározott stratégiai jellegü feladatokra koncentrált funkcióik kijelölésekor vagy pedig széles irányítási jogkörökkel rendelkezö területi egységek létrehozására törekszik; milyen választási rendszer alapján szerveződnek meg a regionális testületek; miként alakul finanszírozási rendszerük, lesz-e adókivetési joguk; milyen elvek alapján müködjön a régiók jogszabályalkotása; milyenek lesznek kapcsolataik a települési és a megyei önkormányzatokkal.

A régióépités intézményesitésében három szakaszt célszerủ elkülöniteni. Az első fázis a teruiletfejlesztés törvényi szabályozásával már kezdetét is vette: a regionális fejlesztési tanácsok - ha megfelelő pénzügyi forrásokhoz jutnak és személyi állományuk is megerósödik - stratégiai koordinációs feladatokat láthatnak el térségük fejlesztési programjainak kidolgozásában és a teruletfejlesztési támogatások felhasználásában. Ez az egyáltalán nem ideális szervezeti megoldás azonban alkalmas lehet arra, hogy a területfejlesztés szereplöi elsajátítsák a regionális politika mủködésének alapszabályait, gyakorlatra tegyenek szert a partneri együttmüködés szervezésében, saját szervezeti rendszerüket is felkészíthessék a regionális fejlesztésekben való közremúkődésre. Ez a viszonylag rövid átmeneti szakasz az elócsatlakozás végén befejeződne.

A második szakasz - a kozjogi régió megszervezése - az Európai Unió teljes jogú tagságával kezdődik. A régió e formája kezdetben még nem jelent jogalkotási szabadságot, csupán a központi kormány hatáskơréböl átadott feladatok végrehajtásának felelősségét és eszközeit decentralizálják. A régióban választott testület alakul, emellett szakapparátus mükődik. Ebben -az új európai programozási időszak kezdetéig, 2007-ig terjedö - szakaszban átalakulnak az állami területi dekoncentrált szervek is, új struktúrájuk a közigazgatási régiókhoz igazodik, feladataik egy részét a megyei vagy a regionális önkormányzatok integrálják.

A teljes jogú tagság első teljes programozási időszakát Magyarország az európai gyakorlattal kompatibilis decentralizált állami berendezkedés keretei kőzött kezdi meg. Az irányítási funkcióiban megújult állam, a jogalkotási felelősséggel felruházott regionális és megreformált megyei és helyi ơnkormányzatok a közös feladatra, Magyarország térszerkezetének modernizálására összpontosithatják erőforrásaikat. 


\section{Irodalom}

Agenda 2000. For a Stronger and Wider Europe 1997: Brussels, European Commission.

Amin, A.- Thrift, N. (szerk.) (1994) Globalisation, Institutions, and Regional Development in Europe. Oxford, Oxford University Press.

Amin, A.- Thrift, N. (1995) Globalisation, Institutional "thikness" and the local economy. - Healey, P -Cameron, S. et al. (szerk.) 91-108. o.

Amin, A.-Tomaney, J. (1995) The regional dilemma in a neo-liberal Europe. - European Urban and Regional Studies. 2. 171-188. o.

Armstrong, H. W. - Vickerman, R. W. (szerk.) (1995) Convergence and Divergence Among European Regions. London, Jessica Kingsley Publishers.

Brotchie, J.- Batty, M.-Blakely, E. et al. (szerk.) (1995) Cities in Competition. Productive and Sustainable Cities for the $2 I^{\text {st }}$ Century. Melbourne, Longman Australia.

Cheshire, P. C.-Gordon, S. R. (1995) European integration: the logic of territorial competition and Europe's urban system. - Brotchie, J.-Batty, M. et al. (szerk.) 108-126. o.

Ciciotti, E. (1993) Competitività e territorio. L'economia regionale nei paesi industrializzati. Roma, La Nuova Italia Scientifica.

Conti, S. (1993) Effetto città. L'Europa nella transizione post-socialista. Torino, Fondazione Giovanni Agnelli.

Conti, S.-Spriano, G. (1990) Effetto città. Sistemi urbani e innovazione: prospettive per l'Europa degli anni Novanta. Torino, Fondazione G. Agnelli.

Enyedi Gy. (1994) Regional and urban development in Hungary until 2005. - Hajdú Z.-Horváth Gy. 239-253. o.

Enyedi Gy. (1996) Regionális folyamatok Magyarországon az álmenet időszakában. Bp., Hilscher Rezsỏ Szociálpolitikai Egyesulet.

Enyedi Gy. (1997) Városok a közép-európai átmenetben. - Társadalmi Szemle. 8-9. 42-56. o.

Esterbauer, F. (szerk.) (1992) Regionalismo e federalismo nella costruzione della nuova Europa. Trento, Regione Autonoma Trentino-Alto Adige.

Europe 2000: Outlook for the Development of the Community's Territory, 1991: Brussels. CEC.

Europe 2000+: Cooperation for European Territorial Development, 1994: Brussels, CEC.

European Spatial Development Perspective. First official draft, (1997) Nordwijk, Informal meeting of Ministers responsible for spatial planning of the Member States of the EU.

Faragó L. (1991) Posztmodern: a modernizáció kritikaja avagy új kihívás. - Tér és Társadalom. 4. 1-16. 0 .

Grundlagen einer Europäischer Raumentwicklungspolitik (1995) Bonn, Bundesministerium für Raumordnung, Bauwesen und Städtebau.

Hajdú Z.- Horváth Gy. (szerk.) (1994) European Challanges and Hungarian Responses in Regional Policy. Pécs, Centre for Regional Studies.

Healey, P. - Cameron, S. - Davoudi, S. et al. (szerk.) (1995) Managing Cities. The New Urban Context. Chichester, John Wiley and Sons.

Horváth Gy. (szerk.) (1993a) Régiók és városok az olasz modernizációban. Régiók Európája 1. Pécs, MTA Regionális Kutatások Központja.

Horváth Gy. (szerk.) (1993b) Development Strategies in the Alpine-Adriatic Region. Pécs, Centre for Regional Studies.

Horváth Gy. (szerk.) (1997) Régiók felemelkedése és hanyatlása. Regionális átalakulás a Britszigeteken. Régiók Európája 2. Pécs, MTA Regionális Kutatások Központja.

Illeris, S. (1994) Essays on Regional Development in Europe. Roskilde, Roskilde University.

llleris, S. (1996) The Service Economy. A Georaphical Approach. Chichester, John Wiley and Sons.

Keating, M. (1998) What's wrong with asymmetrical government? - Regional and Federal Studies. 1. $195-218,0$.

Keating, M. - Loughlin, J. (szerk.) (1997) The Political Economy of Regionalism. London, Frank Cass.

King, A. D. (szerk.) (1991) Culture, Globalisation and the World System. London, Macmillan.

Kunzmann, K. - Wegener, M. (1991) The Pattern of Urbanisation in Western Europe, 1960-1990. Dortmund, Universităt Dortmund.

Raffay Z. (1996) A szolgáltatások osztályozása és szerepük a regionális fejlödésben. - Tér és Társadalom. 2-3. 167-178. o.

Smith, A. D. (1990) Towards a global culture? - Theory, Culture and Society. 1. 171-191. o.

Späth, L. (1991) 1992 - Európa álma. Bp., Közgazdasági és Jogi Kơnyvkiadó.

VASAB, Vision and Strategies around the Baltic Sea 2010, (1994) Tallin, Third Conference of Ministers for Spatial Planning and Development. 


\section{PERSPECTIVES OF REGIONAL DEVELOPMENT AND POLICY IN EUROPE}

\section{GYULA HORVÁTH}

The essay surveys the future of regional development, based on the experiences of regional development and policy in Europe in the 20th century.

The first chapter analyses the cohesion and differentiation of the European space, summing up the long-term processes that contribute to the formation of the space and the possible directions of the development of trans-national regions. One of the conclusions drawn by the author is that the space-forming role of the globalisation will be the most influential in the beginning of the 21 st century, which may result in a strong differentiation if the development policies of the less developed regions fail to react effectively enough to the new challenges. In the development strategies, the knowledge of the operation of the regional economy is especially important. The decrease of the limiting role of the state borders within the European integration, the institutionalised development of the European economic space and the Eastern enlargement of the European Union put the development perspectives of the crossborder regions into a new light. When increasing the competitiveness of the continent, besides the community, national and sub-national frameworks we also have to consider the European macro-regions as important strategic units, those large-capacity regions which are suited to meet the criteria of the economies of scale, the long-term development of the integrated network systems and the increase of the efficiency.

The major political trend in the new century will be decentralisation. A basic interest of the nation states will be in the future to try to compensate the external pressure, coming from the globalisation and integration, by increasing their power over the economic policy, increasing the decisionmaking potential within the countries and enhancing the abilities of the regions to enforce their interests. The traditional development practice of the Keynesian economic policy can no longer be used successfully in the new paradigm, the regional policy of the state is replaced by the own policies of the regions. This change of paradigm, however, cannot occur automatically, the interests of the regions at different development levels in the institutionalisation of the regionalism vary to a significant extent, not to mention the differences in the decentralisation concepts of the governments in the Central-East European countries.

The second part of the study deals with the challenges of the Hungarian regional policy. The main elements in the economic transformation, which influence the long-term trends of the economic growth and the evolution of the spatial structure, are the following: desindustrialisation, tertiarisation, change of technology, decentralisation, European integration and sustainable development. Based on these expected effects, the author defines the current tasks of the Hungarian regional policy. He states that the future of the spatial structure of Hungary basically depends on the decentralisation strategy that Hungary will apply in the use of the new resources available after the EU accession. Regions will be necessary in Hungary, as 
the practice of regional development in Europe has clearly demonstrated that it is the sub-national level with a population of 1.5-2 million inhabitants, administered by local governmental principles, i.e. the regions, which are best suited for economic development and the enforcement of the regional interests. Finally, the essay outlines the perspectives of the institutionalisation of region-building in Hungary. 